\title{
Characterization of tirsification soil weathering processes: The case of Los Lirios wetland, Guadalquivir basin, Seville, Spain
}

\author{
José Manuel Recio ${ }^{1 *}$, Marco A. Sandoval ${ }^{2}$, Cesareo Borja ${ }^{3}$, Fernando Díaz ${ }^{3}$, \\ Francisco Borja ${ }^{4}$, and José Ubera ${ }^{5}$
}

\section{ABSTRACT}

The "Andalusian Black Lands" (Chromatic Vertisols) are soils of great ecological and productive importance, emphasizes their fertility, however, their formation is still a reason for discussion. The main objective of this work was to analyze the most recent geomorphological and environmental evolution and the physical-chemical behavior of some parameters along its profile (Chromatic Vertisols). This study was conducted in Los Lirios wetland of the Guadalquivir basin (Seville, Spain). In addition, samples were obtained in an exploration of the bottom of this wetland for a study on pollen. Samples were obtained to a depth of $260 \mathrm{~cm}$ every $6 \mathrm{~cm}$ in the $120 \mathrm{~cm}$ upper soil layer. Physicochemical characteristics of samples were determined in the laboratory. A total number of 20 samples were evaluated, 11 of which correspond to the $65 \mathrm{~cm}$ of compact horizons submitted to tirsification. Radiocarbon dating $\left(\mathrm{C}^{14}\right)$ was performed by Beta Analytic (Miami, Florida, USA). The results indicate the formation of a cumulative glacis and a subsequent environmental change towards more hydromorphic conditions might account for the surface and physical-chemical processes that characterize this alterological process, which generates soils of high ecological significance and agricultural productivity.

Key words: Black soil forming, wetland Andalusia, Spain.

${ }^{1}$ Universidad de Córdoba, Facultad de Ciencias, Campus Universitario de Rabanales, Carretera Madrid km 396, 14071-Córdoba, España. "Corresponding author (bv1reeesj@uco.es).

${ }^{2}$ Universidad de Concepción, Facultad de Agronomía, Av. Vicente Méndez 595, Chillán, Chile.

${ }^{3}$ Universidad de Sevilla, Facultad de Geografía e Historia, C/S. Fernando 4, CP 41004-Sevilla, España.

${ }^{4}$ Universidad de Huelva, Facultad de Humanidades, Avda. Tres de Marzo s/n, 21071-Huelva, España.

${ }^{5}$ Universidad de Córdoba, Departamento Botánica, Ecología y Fisiología Vegetal, Campus de Rabanales, 14071-Córdoba, España.

Received: 4 May 2017.

Accepted: 29 August 2017.

doi:10.4067/S0718-58392017000400406

\section{INTRODUCTION}

Tirsification (from the latin 'tirs', meaning 'clay' or 'compact') is a complex pedological process that results from a number of ecological processes, such as the presence of substrates rich in smectite clays and the existence of flat or slightly low-lying lands (depression) intensely affected by seasonal hydromorphism . Because of this, organic matter evolves differently, and significant descarbonation and desalinization of the soil profile occur. Additionally, $\mathrm{pH}$ values in the soil are slightly acid, dissolving $\mathrm{Fe}$ and $\mathrm{Mn}\left(\mathrm{Fe}^{2+}\right.$ and $\left.\mathrm{Mn}^{2+}\right)$. The intense black color, which is typical of this type of soil (Schwertmann, 1993; Nguetnkam et al., 2007; Borja et al., 2010; Porta et al., 2013). Besides these conditions lead to the formation of Vertisols (Duchaufour, 1984; Nordt et al., 2004; Nordt and Driese, 2010), Typic Cromoxerets according to Soil Conservation Service (1975), Chromic Vertisols (FAO, 1989), or Andalusian Black Earths (González-García et al., 1962; CEBAC, 1971; Verheye and de la Rosa, 2005), which correspond to soils with high agrological capacity locally called 'bujeos'. These authors and classification systems describe two different influences in their genesis: one predominantly lithological (lithomorphs) and another that corresponds to topo-lithomorphs, which in turn depend on the geomorphological conditions given by the topographical relief (surface processes and slope).

Due to their intense black color, these soils resemble Ukrainian Chernozems, but both formations show very significant differences (Núñez et al., 1997). Similar formations can be also found in the north of Morocco (Bouabid et al., 1996; Moujahid and Bouabid, 2015), where they are known as 'tirs' because of this edaphogenetic process (Real Sociedad Española de Historia Natural, 1914; Huguet del Villar, 1950).

Studies conducted during the early and mid-1900s considered that the formation of these soils was associated with old rainy climates and/or related to the bottoms of extensive wetland areas (Hernández-Pacheco, 1915; Dantín Cereceda, 1929; Huguet del Villar and Robinson, 1937; Fischer et al., 2008; Nordt and Driese, 2010). The presence of Paleolithic industry incorporated into the edaphic mass was described at that time (Breuil, 1917), and it has been also discussed in more recent studies conducted by Martínez (2012) and Araque (2014). According to Díaz and Recio (1991), these paleosoils might be related to the Holocene Climatic Optimum (post glacial climatic optimum), which coincides with the Atlantic period (7450-4450 BP).

All the necessary pedological requirements for the formation of this type of soil seem to be met in Los Lirios wetland (Fuentes 
de Andalucía, Seville, Spain). Therefore, this location constitutes a study site where the geomorphological and environmental evolution of the soil can be studied, and the physical-chemical behavior of some parameters along the soil profile can be analyzed. The objective of this work was the study of the process of tirsification, in the formation of the Chromic Vertisols, analyzing geomorphological, climatic and vegetation environmental change necessary for its formation.

\section{MATERIALS AND METHODS}

The place of the studio is located in Los Lirios wetland (37²6'9" N; 517'49" W), Guadalquivir basin, Seville, Spain. The climate of the province of Seville is continental Mediterranean with a clear oceanic hue. The annual average temperature oscillates between 18 and $20{ }^{\circ} \mathrm{C}$. Winters are mild, spring and autumn are warm and summers are dry and very hot, reaching $\max 40{ }^{\circ} \mathrm{C}$ during July and August. Rainfall, with an average of $650 \mathrm{~mm}$ per year, occurs mainly between October and April, with December being the rainiest month. Samples were obtained to a depth of $260 \mathrm{~cm}$ using a percussion hammer (HM1800, Makita, La Mirada, California, USA) and taking samples every $6 \mathrm{~cm}$ in the $120 \mathrm{~cm}$ upper soil layer. Physicochemical characteristics of samples were determined in the laboratory. A total 20 samples were evaluated (Table 1).

Data provided by the cartography of the Geological Map of Spain (Magna series, scale 1:50.000, nr 986) were interpreted and modified (IGME, 1977), using the topographic map of Andalusia at a scale 1:10.000 and interpreting the aerial photograph from the American flight in 1956. Google satellite images were also used.

Table 1. Physicochemical characterization of studied samples $(\mathbf{n}=20)$.

\begin{tabular}{|c|c|c|c|c|c|c|c|c|}
\hline Depth & $\mathrm{C}$ & $\mathrm{P}$ & $\begin{array}{l}\text { Cal. } \\
\text { act. }\end{array}$ & EC & Wet. & $\mathrm{CO}_{3}$ & $\mathrm{Fe}$ & $\mathrm{Mn}$ \\
\hline $\mathrm{cm}$ & $\%$ & $\mathrm{mg} 100 \mathrm{~g}^{-1}$ & $\%$ & 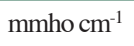 & \multicolumn{2}{|c|}{$-\%-$} & \multicolumn{2}{|c|}{$\mathrm{mg} 100 \mathrm{~g}^{-1}$} \\
\hline $0-2$ & 1.44 & 3.96 & 1.68 & 2.12 & 8.71 & 9 & 124 & 21 \\
\hline $4-6$ & 1.02 & 4.38 & 1.44 & 2.42 & 8.69 & 8 & 104 & 27 \\
\hline $10-12$ & 1.02 & 4.14 & 1.68 & 2.64 & 8.80 & 10 & 104 & 18 \\
\hline $16-18$ & 1.26 & 3.76 & 1.92 & 4.08 & 9.54 & 8 & 111 & 20 \\
\hline $22-24$ & 1.32 & 3.02 & 1.20 & 4.12 & 8.55 & 12 & 102 & 19 \\
\hline $32-34$ & 0.90 & 3.32 & 1.80 & 5.44 & 8.40 & 9 & 91 & 15 \\
\hline $38-40$ & 0.60 & 3.84 & 1.44 & 6.10 & 8.70 & 10 & 85 & 14 \\
\hline $44-46$ & 0.66 & 3.22 & 1.32 & 4.96 & 9.80 & 17 & 84 & 14 \\
\hline $50-52$ & 0.66 & 3.46 & 1.44 & 6.54 & 8.53 & 5 & 83 & 13 \\
\hline $58-60$ & 0.78 & 6.74 & 2.16 & 9.94 & 8.41 & 10 & 84 & 12 \\
\hline $62-64$ & 1.02 & 3.76 & 1.68 & 10.68 & 7.92 & 16 & 100 & 7 \\
\hline $66-68$ & 0.84 & 2.86 & 2.28 & 9.46 & 8.46 & 16 & 130 & 17 \\
\hline $72-74$ & 0.72 & 10.72 & 2.52 & 14.30 & 7.68 & 16 & 139 & 11 \\
\hline $78-80$ & 0.42 & 2.38 & 2.76 & 15.36 & 8.15 & 18 & 114 & 16 \\
\hline $84-86$ & 0.30 & 2.50 & 3.48 & 11.40 & 7.79 & 22 & 81 & 11 \\
\hline $90-95$ & 0.54 & 14.78 & 2.64 & 11.72 & 9.20 & 12 & 94 & 8 \\
\hline $99-101$ & 0.30 & 7.16 & 2.04 & 9.86 & 7.53 & 16 & 90 & 3 \\
\hline $101-103$ & 0.48 & 9.32 & 2.88 & 13.72 & 6.96 & 15 & 106 & 6 \\
\hline $107-109$ & 0.24 & 4.40 & 6.60 & 9.90 & 3.89 & 59 & 41 & 9 \\
\hline $113-115$ & 0.60 & 4.36 & 2.88 & 13.70 & 6.98 & 18 & 129 & 6 \\
\hline
\end{tabular}

Cal. act: Activated limestone; EC: electrical conductivity; Wet.: water content.
The following parameters were studied in the laboratory: color (with Munsell); $\mathrm{pH}$ in water; electrical conductivity (EC); soil moisture; organic $\mathrm{C}$ and mineralized organic matter (OM; Sims and Haby, 1971); P Olsen; total carbonates $\left(\mathrm{CO}_{3}{ }^{\circ}\right)$ and active limestone (Duchaufour, 1975); texture (pipette method); magnetic susceptibility (MS; Dearing, 1999); clay mineralogy (Brindley and Brown, 1980); and determination of Fe and Mn forms (Mehra and Jackson, 1960). Radiocarbon dating $\left(\mathrm{C}^{14}\right)$ was performed by Beta Analytic (Miami, Florida, USA).

The pollen samples used were taken from the lower part of the wetland. Laboratory treatment for pollen samples, pollen isolation, and soil debris separation were performed according to the conventional methodology (Girard and Renault-Miskovsky, 1969; Dupré, 1979; Moore et al., 1991; Saa Otero et al., 1996). The pollen zones were visually determined on the basis of the variation of the preponderant taxa at the percentage level and with emphasis on the trends observed, the plant dynamics is discussed by virtue of climatic, historical and edaphic conditions and in the context of previous studies in the regional scope and in the Mediterranean basin (Yll et al., 2003), and the reference library of the Department of Botany Ecology and Plant Physiology of the University of Cordoba, Spain.

The design directed to a selection of sites, taking 20 randomly sub-samples, the study site was centered on a 10 ha area. Results were subjected to an analysis of correlation (Pearson) considered significant $P \leq 0.05$.

\section{RESULTS Y DISCUSSION}

Figure 1 shows the location and geologicalgeomorphological context of the study area. The higher areas of relief around $170 \mathrm{~m}$ a.s.l. are made up of hard white Miocene limestones (10YR 8/2), rich in carbonates (97\%) and smectites in their insoluble residue (97\%), this characteristic last of Vertisols (Coulombe et al., 1996; Ray et al., 2006). Miocene layers, which are stratigraphically located above them but lying on the bottom of the relief at $140 \mathrm{~m}$ a.s.1., are brown to yellowish brown color (10YR $6 /(\mathrm{s})$ and 10YR 4/(h)), containing $84 \%$ clay and $90 \%$ smectites in their clay fraction. The interaction of the iron oxides with the clays depends on the $\mathrm{pH}$; at low $\mathrm{pH}$, the oxides precipitate on the surface of the clay minerals and, once these coatings are formed, they are stable at elevated $\mathrm{pH}$ (Peacock y Rimmer, 2000). Climate and depth of deposition of smectite in sedimentary environments is directly related to the high level of water, as well as warm and mode rate climates conditions with alternating grey and wet seasons that it changes frequently (Adatte et al., 2002). Iron oxides are useful field indicators of pedogenic environments for three reasons: (i) they include several minerals, (ii) these minerals have different colors, and (iii) the type of mineral formed is influenced by the environment. Therefore, recognizing the Fe-oxide mineral in the field by its color has a potential to yield information about pedogenesis (Schwertmann, 1993). When soil is 
Figure 1. Location and geological context of studied area.

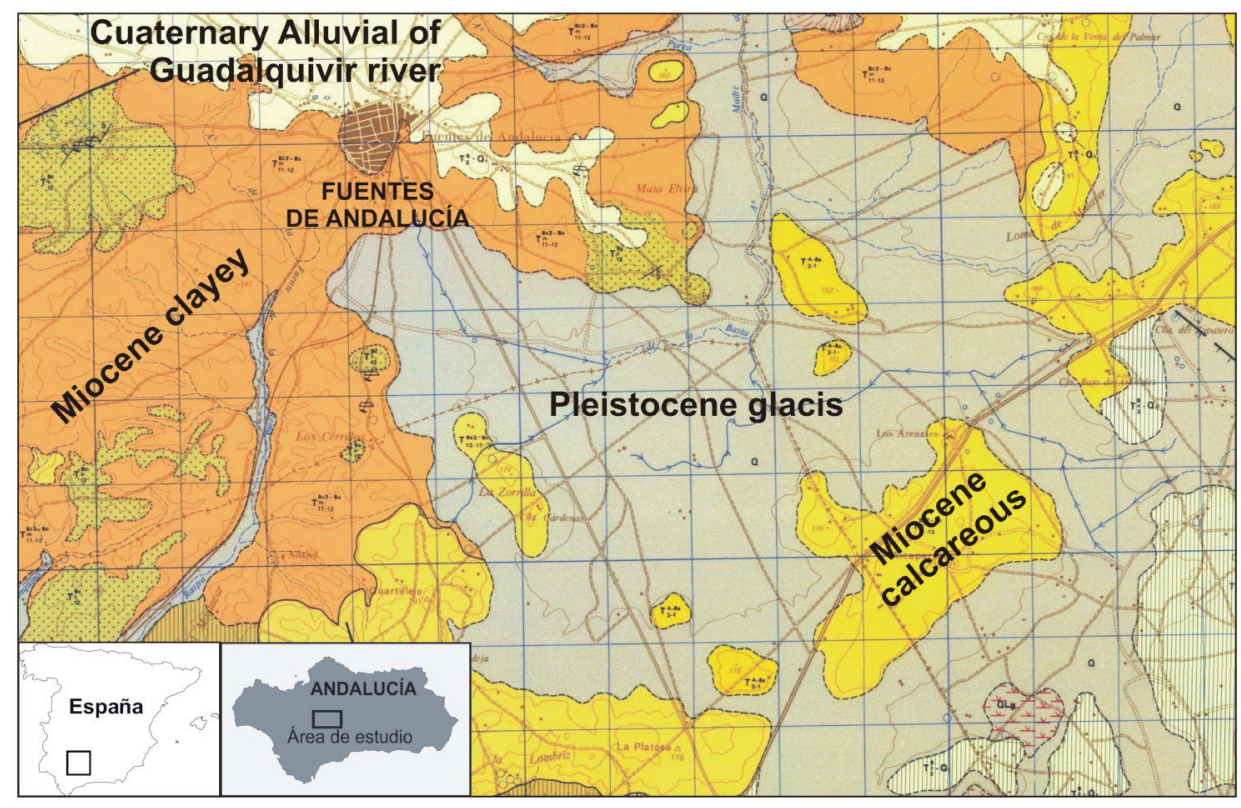

waterlogged, $\mathrm{Fe}^{3+}$ is reduced to $\mathrm{Fe}^{2+}$, and this is reflected in an increase in $\mathrm{Fe}$ solubility. Overall, ion $\mathrm{Fe}^{2+}$ is moderately mobile in the secondary environment, whereas $\mathrm{Fe}^{3+}$ has a very low mobility. It is noted that the mobility of $\mathrm{Fe}$ in soil is largely controlled by the solubility of $\mathrm{Fe}^{3+}$ and $\mathrm{Fe}^{2+}$ amorphous hydrous oxides, although the formation of other Fe compounds, such as phosphates, sulfides and carbonates, may greatly modify $\mathrm{Fe}$ solubilities. The reactions of $\mathrm{Fe}$ in weathering processes are dependent largely on pH-Eh, and on the oxidation state of the Fe compounds involved. In general, oxidizing and alkaline conditions promote $\mathrm{Fe}$ precipitation, whereas acid and reducing conditions favor the solution of $\mathrm{Fe}$ compounds; therefore, acid soil tends to have higher levels of soluble inorganic $\mathrm{Fe}$ compounds than neutral and calcareous soil types (Kabata-Pendias and Pendias, 2000). Based on these lithologies, Figure 2 outlines the existing cumulative glacis from the Pleistocene

Figure 2. Glacis accumulative and tirsified zone.

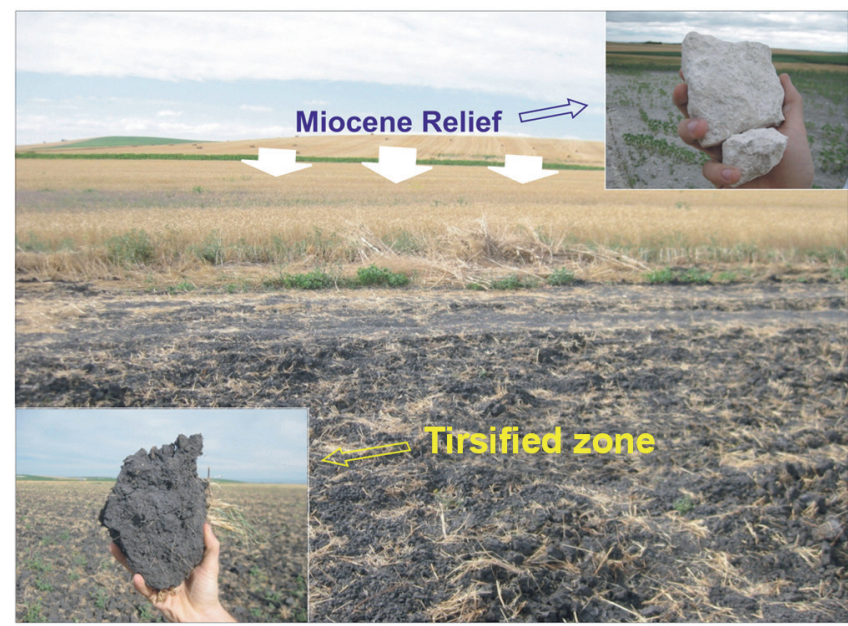

chronology according to IGME (1977), which forms the entire depression. This deposit presents values of $30 \%-$ $40 \%$ carbonates and $75 \%$ clay ( $75 \%$ is expansive clay). It is located in the interfluvial zone between the courses of the Guadalquivir and Corbones rivers; it presents limestone reliefs that surround the depression but no slopes are found. A number of streams that flow to the main fluvial artery barely affect the area.

All these features make drainage of seasonal rainwater difficult, so that a whole network of canals has been constructed to prevent this autumn-winter hydromorphism, and allow for the agricultural use of these soils, mainly for the production of wheat and/or sunflower crops (Figure 3). Slow lateral surface drainage causes intense tirsification on the surface of the glacis up to $65 \mathrm{~cm}$ depth (10YR 4/1 'dark gray'), resulting in carbonated (contents of 10\%) and with more detritus material ( $31.4 \%$ sand), but rich in clay material (57.6\%), of which $73 \%$ corresponds to expansive clay (Figure 4).

Brownish colors (10YR) correspond to the lower part of the initial vertisolized glacis and the presence of a calcic Vertisol (FAO, 1989) (Figure 5). These colors evolved into $10 \mathrm{YR} 4 / 1$, which is the typical 'dark gray' of the hydromorphism that affects the $65-\mathrm{cm}$ surface layer of the Chromic Vertisol (FAO, 1989). There is no uniformity in the color of its different layers or horizons, which vary from brown to even redder tones (7.5YR) in some areas of this Vertisol (Figure 5).

Figure 5 shows the depth evolution of total carbonates and active limestone. Decarbonation occurs with contents ranging from $60 \%$ at $110 \mathrm{~cm}$ depth to $10 \%$ at $55-60 \mathrm{~cm}$, which coincides with the lower limit of the tirsified zone. These values are constant along the profile, same as finely divided carbonate (active limestone) with values around 1.5\%. 
Figure 3. Core location and network canals in tirsified zone.

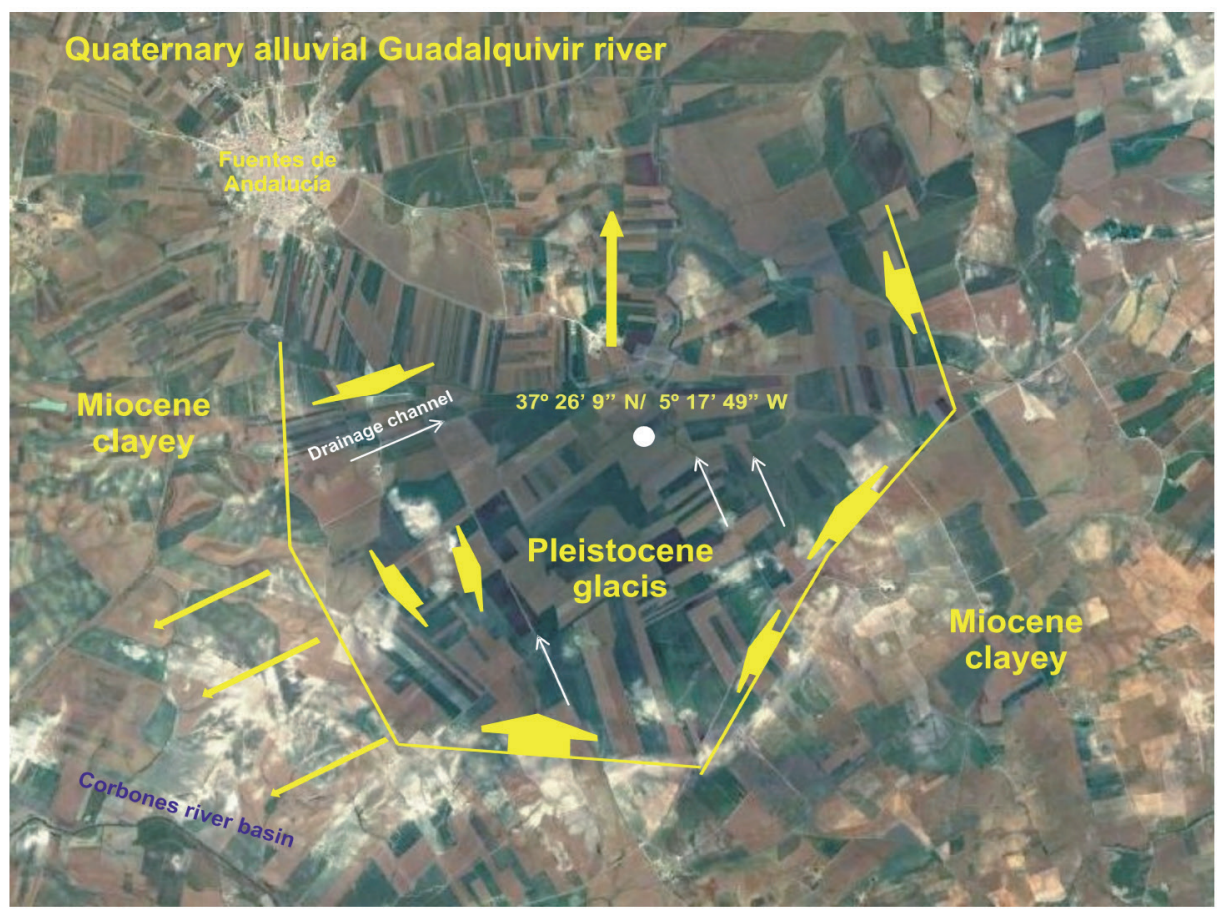

Figure 4. Texture, clay mineralogy and radiocarbon dating.

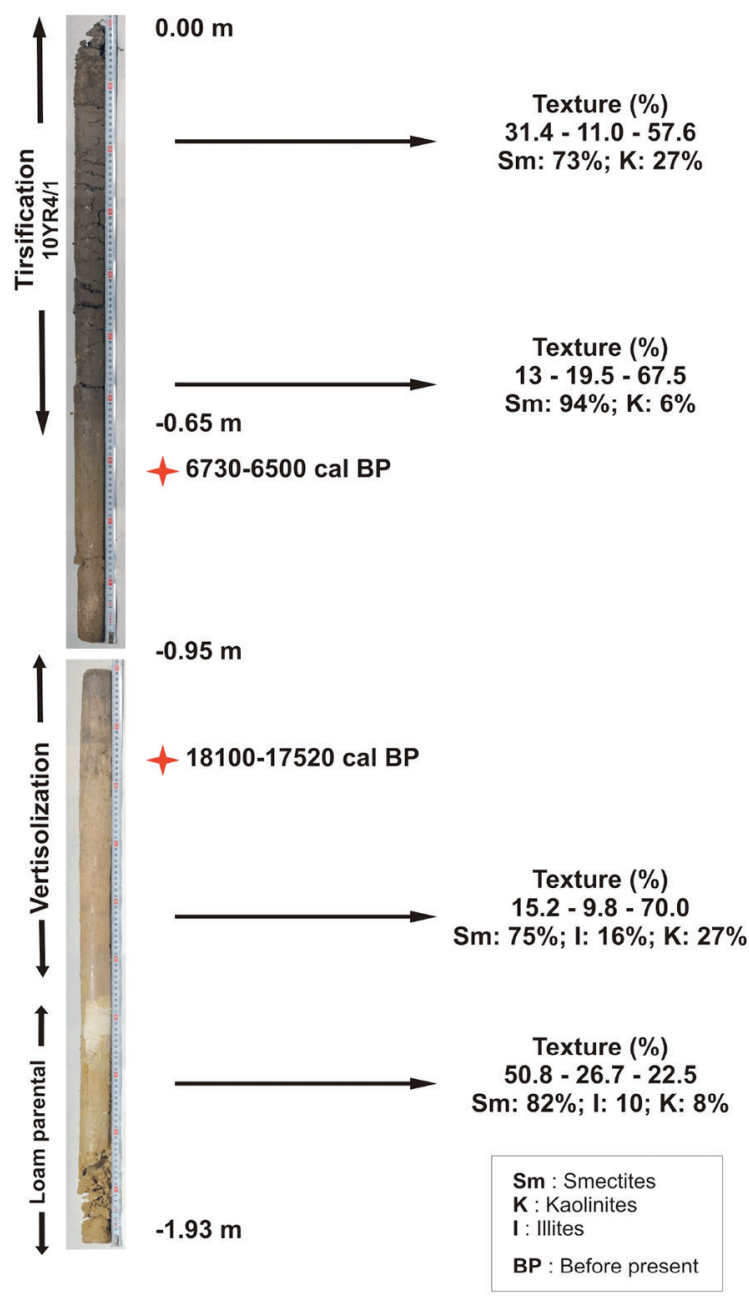

Soil desalination occurs gradually towards the surface layers, ranging from $15-16 \mathrm{mhs} \mathrm{cm}^{-1}$, which coincide with the base of the tirsification, to $2 \mathrm{mhs} \mathrm{cm}^{-1}$ on the surface (Figure 5). Manganese content (Mn-dithionite) also increases towards the surface layers as the hydromorphism acts and penetrates the more subsurface layers of the profile,

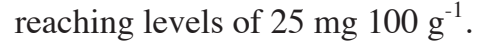

A similar behavior is observed with Fe levels (Fedithionite), reaching values of $120 \mathrm{mg} 100 \mathrm{~g}^{-1}$ on the surface (Figure 4). Therefore, Fe amount is higher than that of Mn as described by Huguet del Villar and Robinson (1937), while the maximum levels are reached at depths in which tirsification begins. This seems to indicate a greater degree of alteration in this area, and it might be related to the presence of an old horizon buried in the calcareous paleoVertisol (FAO, 1989) developed on the glacis that is not tirsified.

This assumption is supported by the behavior of $\mathrm{C}$ content $(\mathrm{C} \%)$ at different depths (Figure 5). Values of $1.02 \%$ found in the base of the tirsification, and the morphology of the curve that represents its distribution in depth provide evidence of the existence of this paleohorizon. Values range from $1.4 \%$ to $1.32 \%$ on the surface at a depth of about $25 \mathrm{~cm}$, which might be related to possible surface vertic movements.

The values of assimilable $\mathrm{P}\left(\mathrm{P}_{2} \mathrm{O}_{5}\right.$-Olsen) (Figure 5) also support this assumption. Levels recorded throughout the tirsified zone are lower than those on its vertisolized base, with values of 4 and 10-12 $\mathrm{mg} 100 \mathrm{~g}^{-1}$, respectively. Therefore, the great agricultural capacity of these tirsified soils seems to be more related to its geomorphological condition more than its chemical fertility, as the former favors a greater availability of water throughout the year 
Figure 5. Evolution of soil parameters in tirsified zone.
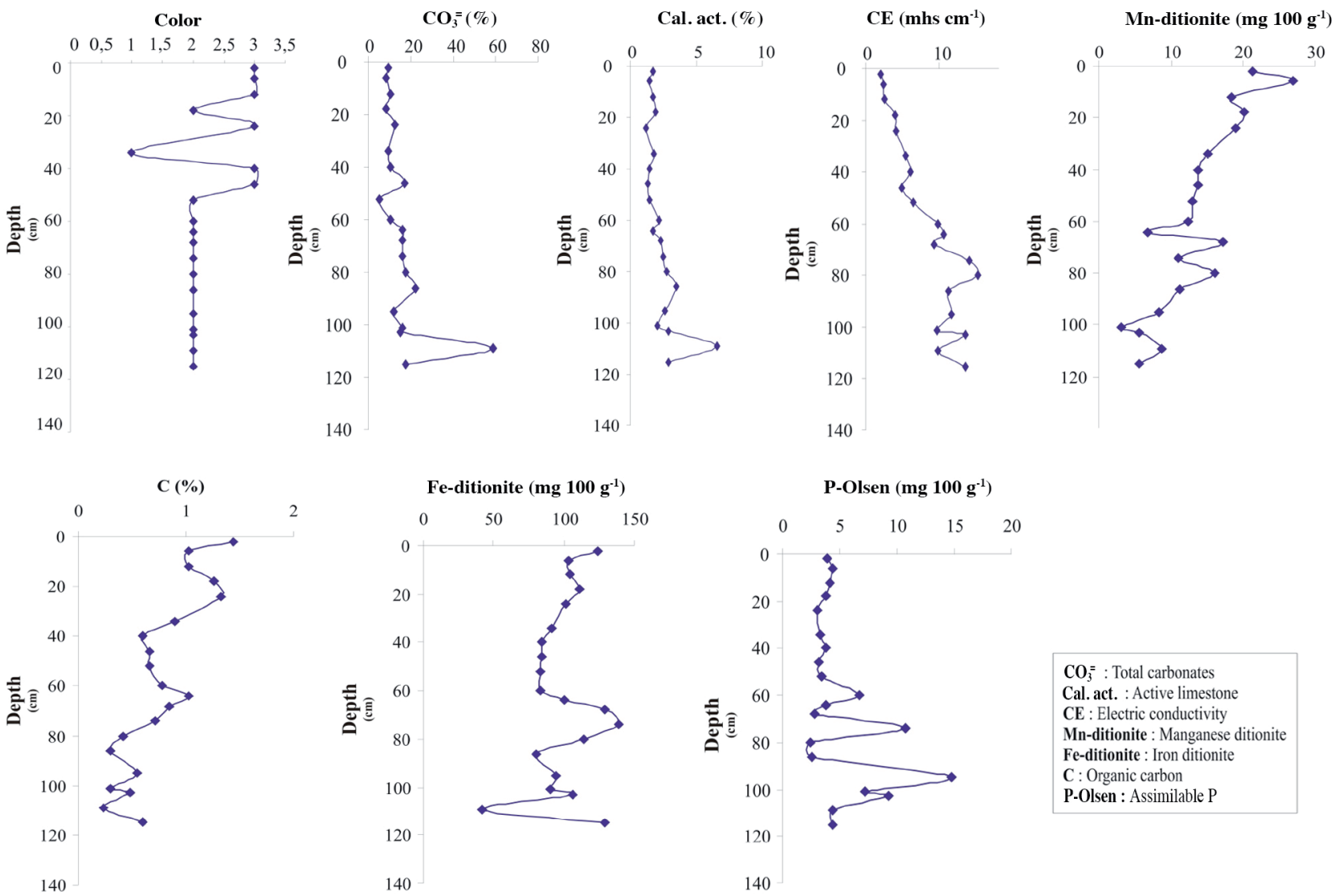

$\mathrm{CO}_{3}=$ : Total carbonates

Cal. act. : Active limestone

$\mathrm{CE}$ : Electric conductivity

Mn-ditionite : Manganese ditionite

Fe-ditionite : Iron ditionite

C: Organic carbon

P-Olsen : Assimilable P

the amount of phosphorus present in the soil solution depends on the extent to which it is adsorbed or desorbed by iron oxides, which may be influenced by interactions with organic matter (Almeida et al., 2003; Fink et al., 2016). Therefore, systems for fertilizer recommendation based on methodologies considering interactions between soil components such as oxides and organic matter. The phosphorus sorption capacity resulting from such interactions (e.g. residual $\mathrm{P}$ analysis), may be more reliable to ensure efficient, rational use of phosphate.

The weathered data and the distribution of the studied parameters at different depths suggest the existence of a polyphasic glacis with at least two formation phases. A first non-hydromorphism is found $150 \mathrm{~cm}$ apart from an earlier edafogenetic process (calcic vertisolization), and a second one with the formation of a tirsified soil (Chromic Vertisol; FAO, 1989) resulting from a less intense drainage network and under a wetland environment. Radiocarbon dating indicates that formation of this tirsified layer dates to 6730$6500 \mathrm{BP}$, while formation of the initial glacis corresponds to 18100-17520 BP (Figure 4).

The study of pollinic sequence provided evidence of this key environmental change (Table 2), as suggested by the great pollen load presented in this last phase compared to the first, the disappearance of Olea europaea and Echium spp. in the hydromorphic environment created, appearance of Chenopodium spp. and absence of phreatophyte plants in an environment of bodies of non-stagnant water. Palynology is a valuable tool when it comes to tackling climate change. The analysis of the pollinic content of a sediment allows an approximation to the existing plant landscape in an area, to define the observed changes and to translate them into climatic terms.

The correlation matrix between parameters defines the dynamics of the alterological process mentioned above (Table 3). Values for Fe and Mn are highly correlated (0.68); the presence of these elements is not compatible with the presence of carbonates $\left(\mathrm{CO}_{3}{ }^{\circ}\right)$, active limestone $(-0.43$ and $-0.40)$ or salts (EC), particularly Mn (-0.71). The hygroscopic moisture is related to the $\mathrm{OM}$ and controls Mn levels (0.49), while the presence of carbonates affects moisture content negatively (-0.85). Organic matter (C) controls almost all other soil parameters, except Olsen $\mathrm{P}$, which is positively dependent on salinity and Mn (0.68), and negatively dependent on carbonate and active limestone levels. 
Table 2. Pollen analysis of plant present in sediment in depth profile.

\begin{tabular}{cc}
\hline (+/-) $50 \mathrm{~cm}$ zone tirsification & $(+/-) 150 \mathrm{~cm}$ zone vertisolation \\
processes & Olea europaea (presence) \\
\hline Olea europaea (disappearance) & Pinus spp. (appearance) \\
Chenopodium spp. (appearance) & Cistus spp. (disappearance) \\
Echium spp. (disappearance) & Maximum Pinus forest \\
Non-hydrophytics plant (presence) & Pollen present \\
Maximum pollen charge & \\
\hline
\end{tabular}

Table 3. Correlation coefficients in soil parameters $(n=20)$.

\begin{tabular}{|c|c|c|c|c|c|c|c|c|}
\hline & $\mathrm{C}$ & $\mathrm{P}$ & $\begin{array}{l}\text { Cal. } \\
\text { act. }\end{array}$ & $\mathrm{EC}$ & Wet. & $\mathrm{CO}_{3}=$ & $\mathrm{Fe}$ & $\mathrm{Mn}$ \\
\hline $\mathrm{C}, \%$ & - & -0.24 & -0.59 & -0.68 & 0.52 & -0.52 & 0.44 & 0.68 \\
\hline $\mathrm{P}, \mathrm{mg} 100 \mathrm{~g}^{-1}$ & - & - & 0.12 & 0.40 & -0.04 & -0.04 & 0.11 & -0.43 \\
\hline Cal. Act., \% & - & - & - & 0.48 & -0.86 & 0.91 & -0.43 & -0.40 \\
\hline 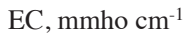 & - & - & - & & 0.46 & 0.33 & 0.13 & -0.71 \\
\hline Wet $\%$ & - & - & - & & & -0.85 & 0.37 & 0.49 \\
\hline $\mathrm{CO}_{3}=\%$ & - & - & - & - & - & - & -0.52 & -0.35 \\
\hline $\begin{array}{l}\mathrm{Fe}, \mathrm{mg} 100 \mathrm{~g}^{-1} \\
\mathrm{Mn}, \mathrm{mg} 100 \mathrm{~g}^{-1}\end{array}$ & - & - & - & - & - & - & & 0.68 \\
\hline
\end{tabular}

Bold numbers: $99 \%$ significance.

Cal. Act: Activated limestone; EC: electrical conductivity; Wet.: water content.

\section{CONCLUSIONS}

The tirsification process occurring in Los Lirios wetland presents the typical features of this pedological process, such as a special transformation of organic matter, decarbonation processes as well as desalination and solubilization of $\mathrm{Mn}$ and $\mathrm{Fe}$.

The soil presents a topo-lithomorphic genesis, with the polyphasic formation consisting of a clay-cumulative Holocene glacis made up of smectites. It presents a slight slope that prevents stagnation, facilitates subsurface flows and results in a weak runoff, as required for the lateral movement of water and removal of soluble products.

A buried paleohorizon serves to separate this tirsified surface glacis from a lower one, which is older and affected by a calcic vertisolization. These environmental conditions and vegetation have guided both edafogenetic processes.

Tirsification does not imply the formation of deep vertic movements to homogenize the profile. The content of soluble $\mathrm{Fe}$ always exceeds that of $\mathrm{Mn}$, while both $\mathrm{Fe}$ and organic $\mathrm{C}$ play a key role in the process. The neosynthesis of smectites is nonsignificant, while the geomorphological position seems to account for its agricultural capacity.

\section{REFERENCES}

Adatte, T., Keller, G., and Stinesbeck, W. 2002. Late Cretaceous to early Paleocene climate and sea-level fluctuations: The Tunisian record. Palaeogeography, Palaeoclimatology, Palaeoecology 178:165-196.

Almeida, J.A., Torrent, J., e Barrón, V. 2003. Cor de solo, formas do fósforo e adsorção de fosfatos em Latossolos desenvolvidos de basalto do Extremo-Sul do Brasil. Revista Brasileira de Ciência do Solo 27:985-1002.
Araque, F. 2014. Industria del Paleolítico antiguo en el valle medio del Guadalquivir. Tesis doctoral, Facultad de Filosofía y Letras, Universidad de Córdoba, Córdoba, España.

Borja, F., Díaz, F., Recio, J.M., y Borja, C. 2010. Procesos de tirsificación y Tierras Negras en el litoral occidental de Cádiz. p. 187-193. In Mata Aguirre, E. (ed.) Interpretación paleográfica de la secuencia Holoceno superior-medio. Cuaternario y Arqueología: Homenaje a Francisco Giles Pacheco. Asociación Profesional del Patrimonio Histórico Arqueológico de Cádiz (ASPHA), Cádiz, España.

Bouabid, R., Badraoui, M., Bloom, P.R., and Daniane, M. 1996. The nature of smectites and associated interstratified minerals in soils of the Gharb plain of Morocco. European Journal of Soil Science 47:165-174.

Breuil, H. 1917. Observations sur les terres noires de la Laguna de La Janda. L'Anthropologie 28:235-240.

Brindley, C.W., and Brown, C. 1980. Crystal structures of clay minerals and their X-ray identification. Mineralogical Society Monograph Vol. 5. 495 p. Mineralogical Society of Great Britain and Ireland, London, UK.

CEBAC. 1971. Estudio agrobiológico de la provincia de Córdoba. 401 p. Publicaciones de la Diputación Provincial de Sevilla, Consejo Superior de Investigaciones Científicas (CSIC), Centro de Edafología y Biología Aplicadas del Cuarto (CEBAC), Sevilla, España.

Coulombe, C.E., Dixon, J.B., and Wilding, L.P. 1996. Mineralogy and chemistry of Vertisols. Developments in Soil Science 24:115-200.

Dantín Cereceda, J. 1929. Localización de las zonas endorreicas en España. Memoria de la Real Sociedad Española de Historia Natural Tomo 15(2):829-836.

Dearing, J.A. 1999. Environmental magnetic susceptibility. Using the Bartington MS2 system. $2^{\text {nd }}$ ed. Chi Publishing, Kenilworth, UK.

Díaz, F., y Recio, J.M. 1991. Lagunas y áreas lacustres continentales de Andalucía occidental (geomorfología, suelos y evolución cuaternaria). Cuadernos de Investigación Geográfica 17(1-2):25-36.

Duchaufour, Ph. 1975. Manual de edafología. 476 p. Editorial Toray-Masson, Barcelona, España.

Duchaufour, Ph. 1984. Edafología. 1. Edafogénesis y clasificación. 493 p. Editorial Masson, Barcelona, España.

Dupré, M. 1979. Breve manual de análisis polínico. 48 p. Instituto Juan Sebastián Elcano, Consejo Superior de Investigaciones Científicas (CSIC), Departamento de Geografía, Universidad de Valencia, Valencia, España.

FAO. 1989. Carte mundiale des sols 1:5.000.000. 125 p. FAO, Rome, Italy.

Fink, J.R., Inda, A.V., Tiecher, T., and Barró, V. 2016. Iron oxides and organic matter on soil phosphorus availability. Ciência e Agrotecnologia 40(4):369-379.

Fischer, H., Luster, J., and Gehring, A.U. 2008. Magnetite weathering in a Vertisol with seasonal redox-dynamics. Geoderma 143(1-2):41-48.

Girard, M., et Renault-Miskovsky, J.L. 1969. Nouvelles techniques de preparation en Palynologie appliqués a trois sediments du Quaternaire final de l'abri Cornille (Istres-Bouches-du-Rhone). Bulletin de l'Association Française pour l'Étude du Quaternaire (AFEQ) 21:275-284.

González-García, F., Guerra A., Guerrero P., Mudurra J., Baños J.L., Chaves, C. et al. 1962. Estudio agrobiológico de la provincia de Sevilla. 1-173. Available at http://hdl.handle. net/10261/48609. 
Hernández-Pacheco, E. 1915. Las tierras negras del extremo sur de España y sus yacimientos paleolíticos. Serie Geológica $\mathrm{N}^{\circ}$ 13. p. 3-24. Trabajos del Museo Nacional de Ciencias Naturales, Madrid, España.

Huguet del Villar, E. 1950. Contribución al estudio comparado de las Tierras Negras de Andalucía y Marruecos. Anales de Edafología y Fisiología Vegetal 9(3):251-278.

Huguet del Villar, E., y Robinson, G.W. 1937. Los suelos de la Península Luso-Ibérica. 416 p. Thomas Murby, London, UK.

IGME. 1977. Hoja geológica seria Magna a escala 1:50.000 (Fuentes de Andalucía). Instituto Geológico y Minero de España (IGME), Madrid, España.

Kabata-Pendias, A., and Pendias, H. 2000. Trace elements in soils and plants. p. 299-304. $3^{\text {rd }}$ ed. CRC Press, Boca Raton, Florida, USA.

Martínez, R.A. 2012. El IV milenio en la Vega del Guadalquivir medio: entorno, sociedad y cultura material. Tesis Doctoral. Universidad de Córdoba, Facultad de Filosofía y Letras, Córdoba, España.

Mehra, O.P., and Jackson, M.L. 1960. Iron oxide removal from soils and clays by a dithionite-citrate system buffered with sodium bicarbonate. 317-327 p. $7^{\text {th }}$ National Conference on Clays and Clays Minerals, Washington. Committee on Clay Minerals of the National Academy of Sciences-National Research Council, Washington, USA.

Moore, P.D, Webb, J.A, and Collinson, M.E. 1991. Pollen analysis. $2^{\text {nd }}$ ed. Blackwell, Oxford, UK.

Moujahid, Y., and Bouabid, R. 2015. Mineralogy and charge of Moroccan vertisoil smectite. Journal of Materials and Environmental Science 6(11):3328-3337.

Nguetnkam, J.P., Kamga R., Villieras, F., Ekodeck, G.E., and Yvon, J. 2007. Pedogenic formation of smectites in a vertisol developed from granitic rock from Kaele (Cameroon, Central Africa). Clay Minerals 42(4):487-501.

Nordt, L.C., and Driese, S.D. 2010. New weathering index improves paleorainfall estimates from Vertisols. Geology 38(5):407-410.

Nordt, L.C., Wilding, L.P., Lynn, W.C., and Crawford, C.C. 2004. Vertisol genesis in a humid climate of the coastal plain of Texas, USA. Geoderma 122:83-102.
Núñez, M.A., Dueñas, M.A., Perevoznick, I.A., y Recio, J.M. 1997. Un estudio comparativo entre Tierras Negras andaluzas y Chernozems ucranianos. p. 355-359. Cuaternario Ibérico, AEQUA, Sevilla, España.

Peacock, S., and Rimmer, D. 2000. The suitability of an iron oxide-rich gypsum by-product as a soil amendment. Journal of Environmental Quality 29(6):1969-1975.

Porta, J., López-Acevedo, M., y Poch, R.M. 2013. Edafologia usos y protección de suelos. 608 p. Mundi-Prensa, Madrid, España.

Ray, S.K., Bhattacharyya, T., Chandran, P., Sahoo, A.K., Sarkar. D., Durge, S.L., et al. 2006. On the formation of cracking clay soils (Vertisols) in West Bengal. Clay Research 25(2):141-152.

Real Sociedad Española de Historia Natural. 1914. Yebala y el bajo Lucus. 320 p. Real Sociedad Española de Historia Natural, Madrid, España.

Saa Otero, M.P., Suárez-Cervera, M., y Gracia, V.R. 1996. Atlas de polen de Galicia. Diputación Provincial de Ourense, Ourense, España.

Schwertmann, U. 1993. Relation between iron oxides, soil color and formation. p. 51-59 In Bighan, J.M., and Ciolkosz, E.J. (eds.) soil color. Soil Science Society of America, Madison, Wisconsin, USA.

Sims, J.R., and Haby, V.A. 1971. Simplified colorimetric determination of soil organic matter. Soil Science 112(2):137-141.

Soil Conservation Service. 1975. Soil taxonomy. A basic system of soil classification for making and interpreting soil surveys. Agriculture Handbook nr 436.754 p. Soil Conservation Service, US Department of Agriculture, Washington DC, USA.

Verheye, W., and de la Rosa, D. 2005. Mediterranean soils. In Land use and land cover. Encyclopedia of Life Support Systems. UNESCO, EOLSS Publishers, Oxford, UK.

Yll, R., García, J.S., Pantaleón, J., Dupré, M., La Roca, N., Roure, J., et al. 2003. Palinología del Cuaternario reciente en la Laguna de Villena (Alicante, España). Anales de Biología 25:65-72. 